Amsterdam Expeditions to the West Indian Islands, Report 36*

\title{
THE GENUS STRANDESIA AND OTHER CYPRICERCINI (CRUSTACEA, OSTRACODA) IN THE WEST INDIES
}

\author{
PART II. CARAPACE LENGTH, ECOLOGY, AND DISTRIBUTION \\ OF TWO STRANDESIA SPECIES
}

by

NICO W. BROODBAKKER

Institute of Taxonomic Zoology, University of Amsterdam, P.O. Box 20125, 1000 HC Amsterdam, The Netherlands

\section{SUMMARY}

The distribution and ecology of two species of Strandesia, $S$. longula Broodbakker, 1983, and S. stocki Broodbakker, 1983 , are discussed. Both species are very common in Haiti, and $S$. longula is also common in the Bahamas. Both are found on some of the Lesser Antilles, and therefore they are assumed to have a much wider distribution.

The two species are mostly found in fresh water, but they can tolerate chlorinities up to $3500 \mathrm{mg} / \mathrm{l}$. No preferences concerning other factors could be found. Both species live in wells, pools, and in the underflow of running waters.

Differences in carapace length of different populations could not be correlated with any environmental factor measured. These length differences do not appear to be determined genetically. It is most probable that differences in carapace length are caused by combined environmental factors, like food abundance, pollution, and factors of water chemistry other than chlorinity, as postulated for the genera Heterocypris and Hemicypris.

\section{RÉSUMÉ}

On discute la distribution et l'écologie de deux espèces de Strandesia, S. longula Broodbakker, 1983, et S. stocki Broodbakker, 1983. Ces deux espèces sont fort communes à Haïti, et $S$. longula est commune aussi aux Bahamas. Les deux ont été trouvées sur certaines des Petites Antilles, et on suppose que leur distribution est beaucoup plus vaste.

Elles ont été trouvées surtout en eau douce, mais peuvent tolérer des taux de chlorinité atteignant $3500 \mathrm{mg} /$. On n'a pas pu trouver des préférences vis-à-vis d'autres facteurs. Les deux espèces vivent dans les puits, dans le

- Report 35 has been published in Bijdragen tot de Dierkunde, 53 (2): 327-368 (1983). sous-écoulement de cours d'eau, et dans des pièces d'eau stagnante.

Les différences dans la longueur de la carapace des différentes populations n'ont pas pu être corrélées avec l'un ou l'autre des facteurs du milieu, et elles ne semblent pas être génétiquement déterminées. Il est fort probable que ces différences sont en relation avec une combinaison de facteurs, tels que l'abondance de la nourriture, la pollution, et des facteurs hydrochimiques autre que la chlorinité ce qui avait déjà été postulé pour les genres Heterocypris et Hemicypris.

\section{INTRODUCTION}

The present article forms the second part of a study on the tribe Cypricercini. The first part (Broodbakker, 1983c) dealt with the genus Strandesia, of which seven new species and one new subspecies were described and discussed.

The two most common species, Strandesia longula and $S$. stocki, were only described and taxonomically discussed. The present paper deals with the ecology and distribution of these two species and the differences in carapace length between animals of different samples.

\section{MATERIAL AND METHODS}

Most of the samples studied have been collected by the Amsterdam Expeditions to the West Indian Islands (19731982), and the expeditions of Dr. P. Wagenaar Hummelinck to many Caribbean islands (1936-1973). The two 
samples from Cuba have been collected by Dr. St. Negrea and Dr. T. Orghidan, in 1969 and 1970. For further details about most samples, the reader is referred to Stock (1979) and Wagenaar Hummelinck (1940a-b, 1953, 1981). The samples of the Amsterdam Expeditions and of Dr. P. Wagenaar Hummelinck are abbreviated in the sequel as $\mathbf{S}$ and $\mathrm{WH}$, respectively. All material is deposited in the Zoölogisch Museum, Amsterdam (ZMA).

Carapace length was measured with a ruler on a sheet of white paper, on which the animals were projected by way of a camera lucida and a Reichert Diapan microscope.

Goodness of fit was computed for frequency distributions arranged by a single criterion of classification. Frequency distributions were calculated for samples containing $S$. longula and/or $S$. stocki, in different classes of the environmental factors (chlorinity, water depth, water table, light conditions, and type of soil). Expected frequencies were calculated in the same way as done for Heterocypris (cf. Broodbakker, 1983a). The same types and classes as in that paper were used.

Instead of chi-square tests, $G$-tests were performed, because the $G$-test has a theoretical advantage over the former, and is computationally simpler (Sokal \& Rohlf, 1981: 704). Critical values for the $G$-test can be found in a chi-square table, the distribution of $G$ approximates the chi-square distribution.

The tests were performed for samples from Haiti, since only from this island enough samples with both Strandesia species were available.

\section{DIFFERENCES IN CARAPACE LENGTH}

(Table I; appendices I-II)

There is more variation in carapace length between populations of $S$. longula than between populations of $S$. stocki. Mean carapace length in Haiti ranges from 1.21 to $1.55 \mathrm{~mm}$ for $S$. longula, and from 0.77 to $0.91 \mathrm{~mm}$ for $S$. stocki. The variation in mean carapace length between the different populations is also larger for $S$. longula than for $S$. stocki, being $1.32 \pm 0.09 \mathrm{~mm}$ $(n=13)$ and $0.83 \pm 0.03 \mathrm{~mm}(n=26)$, respectively.

The variation is not correlated with the geographical position of the stations. In the Département de l'Ouest of Haiti, small as well as large specimens of $S$. longula are found in open wells of low chlorinity. In the Département du Nord the largest and smallest sized populations of $S$. stocki were found (appendix I). A correlation with chlorinity is not found either. The smallest as well as the largest specimens of $S$. longula were found at low chlorinities.

The largest sized population of $S$. stocki was found at a high chlorinity (S 78/236: 3320 $\mathrm{mg} / \mathrm{l})$, but other large-sized populations were found at low as well as at high chlorinities (e.g.: S 78/205, S 78/235, S 79/599; appendix I).

In the few covered wells in which the animals were found in large numbers, they were not distinctly smaller or larger than animals from open habitats.

In the Bahamas only $S$. longula was encountered. Most populations from these islands have smaller carapaces than the populations from Haiti. Mean carapace length on Crooked Island ranges from 1.17 to $1.21 \mathrm{~mm}$, and on San Salvador two populations with mean carapace lengths of 1.15 and $1.22 \mathrm{~mm}$ were found. Only on Eleuthera four larger sized populations were found, ranging in mean length from 1.28 to $1.33 \mathrm{~mm}$ (appendix II).

This means that in general $S$. longula is smaller in the Bahamas, but that the mean carapace lengths still have overlap with those found in Haiti. As in Haiti, carapace length is not dependent on chlorinity or the light conditions in the wells. Small as well as large animals were found under all conditions.

The populations found on St. Martin, St. Eustatius and the Virgin Islands (table I; appendix II) range from 1.19 to $1.33 \mathrm{~mm}$ in mean length.

The populations from Curaçao are relatively large, ranging from 1.39 to $1.53 \mathrm{~mm}$ in mean length. Populations from the same stations taken at different dates had approximately the same length, but the differences in carapace size between animals of the stations WH 75 and WH 82 are very large (table I). The populations from Bonaire and La Désirade have an intermediate mean length.

Conclusions. - No correlations could be found between carapace length and chlorinity or geographic location. Carapace lengths of animals sampled in open and covered habitats were not consistently different either. 


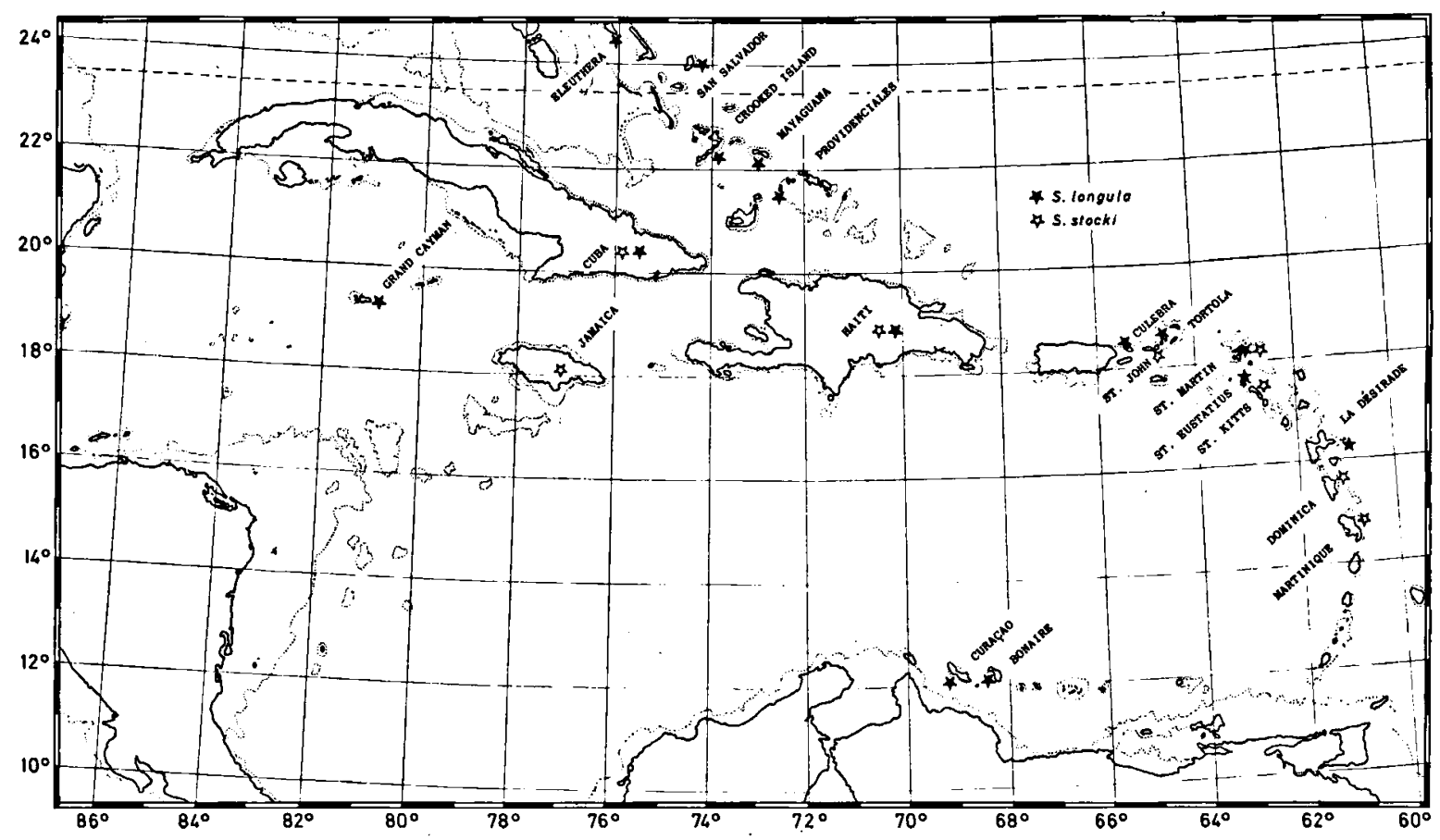

Fig. 1. Map of the Caribbean, showing (dotted) the $200 \mathrm{~m}$ line being the edge of the continental shelf. The distribution of Strandesia longula and $S$. stocki is indicated.

These results confirm the conclusions found in Broodbakker (1983a-b) for the genera Heterocypris and Hemicypris. It is most probable that differences in size are caused by combined environmental factors, like food abundance, pollution, and factors of water chemistry other than chlorinity. A comprehensive discussion of aspects concerning the cause of these size differences is provided by Broodbakker (1983a). It seems improbable that the size differences are caused by genetic factors.

\section{DISTRIBUTION AND ECOLOGY}

Geographical distribution (fig. 1; table I; appendices I-II)

$S$. longula and $S$. stocki are very common species in Haiti. Since only wells, springs and river interstitia were sampled, it is not clear if the species are also common in pools, ponds, and other epigean habitats.

$S$. longula is alșo common in the Bahamas, in contrast to $S$. stocki, which was never found on these islands. Both species live in Cuba, but they were encountered only in epigean habitats and not in the caves sampled by Dr. L. Botosaneanu and Dr. T. Orghidan. Since only few epigean samples were available, and no samples from wells, it is possible that the species is much more common on this island.

$S$. longula was found in two samples from Grand Cayman, and $S$. stocki in one sample from Jamaica. Since only few ostracod samples from these islands were obtained, the two species may be more common here too. Neither of the species was found in Puerto Rico, but only six ostracod samples were available from this island.

The distribution of the two species in the Virgin Islands and the Lesser Antilles is very scattered. $S$. stocki was found in five islands only, in one sample of each island (fig. 1). These stations are listed in part I of this paper (Broodbakker, 1983c: 339). S. longula was encountered in epigean samples on Curaçao, in a pool-like well on Bonaire and on St. Martin, and in a spring on La Désirade (table I). It was 
N. W. BROODBAKKER - WEST INDIAN STRANDESIA, II

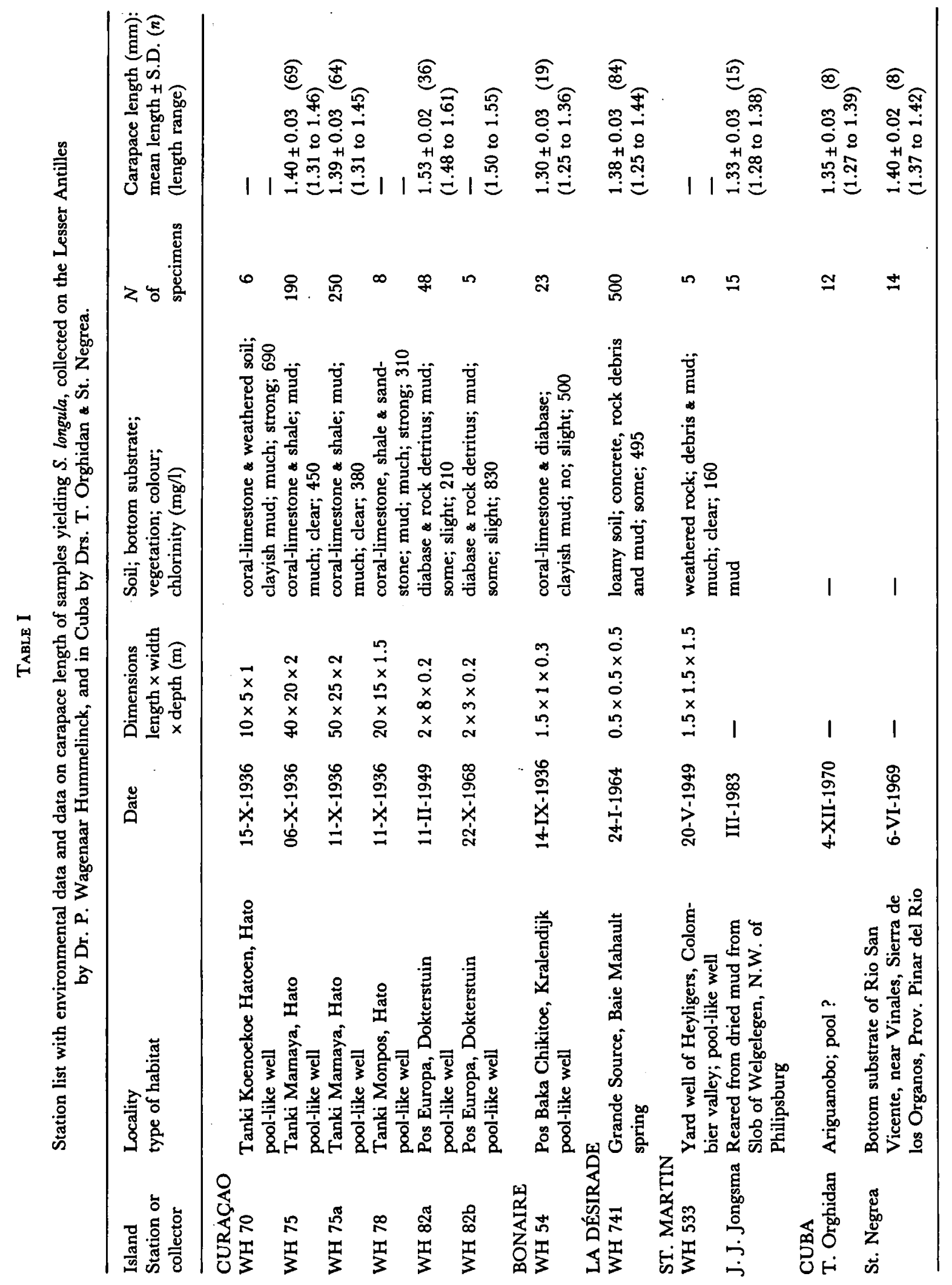


also found in wells on St. Martin, St. Eustatius, Tortola and Culebra (appendix II).

I succeeded in rearing both species from dried mud from St. Martin, this in contrast to the fact that $S$. stocki was only found in 1 and $S$. longula in 3 out of 31 stations sampled on this island. It is therefore highly probable that the two species are more widely distributed, and present on most, if not all, Antillean islands. $S$. longula has the widest distribution, being also common in the Bahamas, while $S$. stocki seems to reach its northernmost distribution in Cuba and Haiti.

\section{Chlorinity (table I; appendices I-II)}

$S$. longula was encountered mostly at low chlorinities, of less than $400 \mathrm{mg} / \mathrm{l}$ in Haiti, but also in samples with chlorinities up to $2815 \mathrm{mg} / \mathrm{l}$ in the Bahamas.

Likewise, $S$. stocki was mostly found at low chlorinities, of less than $300 \mathrm{mg} / \mathrm{l}$, but once at a chlorinity of $3320 \mathrm{mg} / \mathrm{l}$ (S 78/236), and three times at chlorinities reaching from 760 up to $1320 \mathrm{mg} / \mathrm{l}$ (S 78/231-234-235). The samples from the other islands where $S$. stocki was sparsely found, were from stations with chlorinities of $320 \mathrm{mg} / \mathrm{l}$ or less.

Both species seem to be real freshwater species that are able to tolerate chlorinities up to 3000 or $3500 \mathrm{mg} / \mathrm{l}$, but are mostly found at much lower chlorinities.

Light conditions (table I; appendices I-II) In Haiti only one sample containing more than 10 specimens of $S$. longula was collected from a covered well. However, in the Bahamas, especially on Eleuthera, many samples originated from covered wells. Of the wells yielding ostracods in Haiti, only $19 \%$ was covered, while the percentage of samples with (mostly few) specimens of $S$. longula was also $19 \%$. This means that $S$. longula does not specifically avoid covered wells in Haiti. It looks as if $S$. stocki is found more frequently in covered wells, but the higher percentage of samples from covered wells in Haiti $(28 \%)$ is not statistically significant $(G=1.96)$.
Water depth and table

No statistically significant differences were found for either of the species concerning the water depth and table of the wells sampled in Haiti. S. stocki was found relatively more often in waters deeper than $1.2 \mathrm{~m}(G=1.04$; $\left.\chi_{.05[1]}^{2}=3.84\right)$, and in wells with a water table lower than $2 \mathrm{~m}\left(G=5.80 ; \chi_{.05[2]}^{2}=5.99\right)$, but these differences are not significant.

\section{Soil}

The type of soil was not registered for most samples, although for the samples from Haiti it could be determined which samples came from alluvial soils and which from limestone surroundings. But often no other data were available. Both species were found in both soil types.

\section{Accompanying fauna (tables II-IV)}

In table II the number and percentages of wells in Haiti containing one or more of the listed animal groups are given. Furthermore, the number and percentages of wells containing $S$. longula or $S$. stocki, as well as one or more of the animal groups, are listed. The same procedure was performed for the wells from Mayaguana, Crooked Island, San Salvador Island and Eleuthera, for $S$. longula (table IV). These four Bahamas were chosen solely, because $S$. longula was common in these islands only.

For each animal group a $G$-test was performed, to discover if it was significantly found more or less often with either of the Strandesia species, than should be expected from their overall distribution in the wells of these islands yielding ostracods. Most percentages calculated were about the same as those expected from the overall distribution. S. longula was found significantly less with Oligochaeta in the Bahamas, but not in Haiti. In Haiti, S. longula was found considerably less in the presence of hadziid amphipods (table II; the difference is significant at better than $5 \%$ level). Stock (1983) postulates that hadziid amphipods predate on smaller Crustacea, which could mean that they also predate on $S$. longula. However, no such significant relationship was 
TABLE II

Number of samples, with percentages and $G$-values, from wells in Haiti, yielding $S$. longula or $S$. stocki, or other faunal elements.

\begin{tabular}{llclll}
\hline Accompanying fauna & In all wells & \multicolumn{2}{c}{ In wells with $S$. longula } & \multicolumn{2}{c}{ In wells with $S$. stocki } \\
& $(n=97)$ & $(n=33)$ & $G$ & $(n=38)$ & $G$ \\
\hline Cyclopidae & $81(84 \%)$ & $24(73 \%)$ & 2.41 & $30(79 \%)$ & 0.54 \\
Oligochaeta & $55(57 \%)$ & $18(55 \%)$ & 0.06 & $18(47 \%)$ & 1.33 \\
Insecta & $49(51 \%)$ & $16(48 \%)$ & 0.05 & $17(45 \%)$ & 0.51 \\
Gastropoda & $36(37 \%)$ & $10(30 \%)$ & 0.68 & $12(32 \%)$ & 0.51 \\
Thermosbaenacea & $26(27 \%)$ & $9(27 \%)$ & 0.00 & $10(26 \%)$ & 0.05 \\
Cladocera/Phyllopoda & $20(21 \%)$ & $3(9 \%)$ & 3.22 & $6(16 \%)$ & 0.58 \\
Hadziid amphipods & $18(19 \%)$ & $2(6 \%)$ & $4.37^{*}$ & $6(16 \%)$ & 0.20 \\
\hline
\end{tabular}

\section{TABLE III}

Number of samples, with percentage and $G$-values, from wells in Haiti, yielding $S$. longula or $S$. stocki, or other Ostracoda.

\begin{tabular}{lccccc}
\hline Accompanying Ostracoda & In all wells & \multicolumn{2}{c}{ In wells with $S$. longula } & \multicolumn{2}{c}{ In wells with $S$. stocki } \\
& $(n=98)$ & $(n=33)$ & $G$ & $(n=39)$ & $G$ \\
\hline Cypretta sp. & $39(40 \%)$ & $22(67 \%)$ & $9.70^{* *}$ & $13(33 \%)$ & 0.57 \\
S. stocki & $39(40 \%)$ & $17(52 \%)$ & 1.85 & - & - \\
S. longula & $33(34 \%)$ & -- & - & $17(44 \%)$ & 1.65 \\
Stenocypris major (Baird, 1859) & $19(19 \%)$ & $9(27 \%)$ & 1.20 & $12(31 \%)$ & 2.87 \\
Chlamydotheca unispinosa & $37(38 \%)$ & $6(18 \%)$ & $6.00^{*}$ & $12(31 \%)$ & 0.83 \\
Cypridopsis sp. & $7(7 \%)$ & $2(6 \%)$ & - & $2(5 \%)$ & - \\
Physocypria sp. & $12(12 \%)$ & $1(3 \%)$ & 3.60 & $1(3 \%)$ & $4.83^{*}$ \\
Neocypridopsis inaudita & $2(2 \%)$ & $2(6 \%)$ & - & $1(3 \%)$ & - \\
Pseudocandona antilliana & $5(5 \%)$ & $1(3 \%)$ & - & -- & - \\
\hline
\end{tabular}

TABLe IV

Number of samples, with percentages and $G$-values, from wells in Mayaguana, Crooked Island, San Salvador Island and Eleuthera, yielding $S$. longula or other faunal elements.

\begin{tabular}{|c|c|c|c|c|c|c|c|}
\hline $\begin{array}{l}\text { Accompanying } \\
\text { fauna }\end{array}$ & $\begin{array}{l}\text { In all } \\
\text { wells } \\
(n=61)\end{array}$ & $\begin{array}{l}\text { In wells wit } \\
S . \text { longula } \\
(n=37)\end{array}$ & $G$ & $\begin{array}{l}\text { Accompanying } \\
\text { Ostracoda }\end{array}$ & $\begin{array}{l}\text { In all } \\
\text { wells } \\
(n=62)\end{array}$ & $\begin{array}{l}\text { In wells with } \\
\text { S. longula } \\
(n=37)\end{array}$ & $G$ \\
\hline Insecta & $36(59 \%)$ & $27(73 \%)$ & 3.14 & Cypridopsis sp. & $35(56 \%)$ & $22(60 \%)$ & 0.14 \\
\hline Cyclopidae & $31(51 \%)$ & $22(59 \%)$ & 1.11 & Physocypria sp. & $31(50 \%)$ & $14(38 \%)$ & 2.21 \\
\hline Oligochaeta & $15(25 \%)$ & $4(11 \%)$ & $4.50^{*}$ & Cypretta sp. & $15(24 \%)$ & $9(24 \%)$ & 0.00 \\
\hline $\begin{array}{l}\text { Gastropoda (except } \\
\text { for Pyrgophorus) }\end{array}$ & $14(23 \%)$ & $8(22 \%)$ & 0.04 & $\begin{array}{l}\text { Neocypridopsis } \\
\text { inaudita }\end{array}$ & $14(23 \%)$ & $2(5 \%)$ & $8.31^{* *}$ \\
\hline Pyrgophorus & $14(23 \%)$ & $8(22 \%)$ & 0.04 & No other species & -- & 7 & - \\
\hline Amphipoda & $14(23 \%)$ & $9(24 \%)$ & 0.04 & & & & \\
\hline Hyalella sp. & $14(23 \%)$ & $10(27 \%)$ & 0.33 & & & & \\
\hline Cladocera & $6(10 \%)$ & $3(8 \%)$ & - & . & & & \\
\hline
\end{tabular}

* Significant at better than $5 \%$ level (one-tailed).

** Significant at better than $1 \%$ level (one-tailed). 
found for the co-occurrence of $S$. stocki and hadziid amphipods, which could contradict this supposition.

The same procedure as with the animal groups was followed for the wells in Haiti in which $S$. longula and $S$. stocki were accompanied by other ostracod species (table III), and for $S$. longula in the wells of the four Bahamas chosen (table IV). In this procedure more differences in the animal associations were found.

$S$. longula is found relatively often together with Cypretta sp., and relatively less often with Chlamydotheca unispinosa (Baird, 1862), in Haiti. However, this was not the case in the Bahamas. In the islands Mayaguana, Crooked Island, San Salvador and Eleuthera, it was found only slightly more often with Cypretta sp., but not significantly so, and less often with Neocypridopsis inaudita (Furtos, 1936), a species which was not found in Haiti (table IV). Chlamydotheca unispinosa was present in only two ostracod samples from the Bahamas. S. longula was not found relatively more or less often with any of the other ostracod species in Haiti and the Bahamas.

$S$. stocki was found in Haiti only once with Physocypria sp., like $S$. longula. The other species were not found significantly more or less often with $S$. stocki in Haiti.

$S$. longula and $S$. stocki were found somewhat more often in each other's presence than would be expected if they were distributed at random. This means that there certainly is no indication of competition between the two species. Both species are often found together in the same well, and in most of the wells of Haiti they are accompanied by one or more of the other species of ostracods.

Conclusions. - $S$. longula is a common species in the wells of Haiti, but also in the wells of most of the Bahamas. It was also encountered in some epigean samples from Cuba, Curaçao, Bonaire, and La Désirade, and in some wells on Grand Cayman, Tortola, Culebra, St. Martin and St. Eustatius.

S. stocki is most common in Haiti, was never found in the Bahamas, twice in Cuba, and only once on Jamaica, St. Martin, St. Kitts, St. John, Dominica and Martinique.

Both species could be raised from dried mud. It is therefore probable that they have a much wider distribution than is presently known. Both species were encountered on limestone as well as on alluvial deposits (often sand), mostly at low chlorinities (less than $400 \mathrm{mg} / \mathrm{l}$ ), but they can tolerate chlorinities up to $3500 \mathrm{mg} / \mathrm{l}$. No other preferences could be found. Both species live in pools, wells and river interstitia. In Haiti they were often found together and with other species of ostracods in the same sample. $S$. longula was found significantly more often with Cypretta sp. in Haiti, but not in the Bahamas, and less often with Chlamydotheca unispinosa in Haiti, and with Neocypridopsis inaudita in the Bahamas. S. stocki was found significantly less often with Physocypria sp., but this conclusion is based on few samples.

Both species were accompanied by a specific fauna. S. longula was found significantly less often with hadziid amphipods in Haiti, which could be the result of predation by the latter. However, this is in contrast to the fact that $S$. stocki was not found significantly less in the company of hadziid amphipods.

\section{ACKNOWLEDGEMENTS}

Dr. D. L. Danielopol is thanked for his support and the many contributions to my research project. Prof. Dr. J. H. Stock (coordinator of the West Indian project), Dr. L. Botosaneanu and Drs. F. F. J. M. Pieters are thanked for critically reviewing the manuscript.

Dr. P. Wagenaar Hummelinck, Dr. T. Orghidan, and Dr. St. Negrea, kindly placed their samples at our disposal.

This study has been financed by the Netherlands Foundation for the Advancement of Tropical Research (WOTRO), The Hague. The fieldwork of the Amsterdam Expeditions has been supported by grants from WOTRO, the Beijerinck-Popping Fonds (Amsterdam), the Treub Maatschappij (Utrecht), the Amsterdamse Universiteitsvereniging (Amsterdam), and the Fonds Landbouwhogeschool (Wageningen).

\section{REFERENCES}

Broodbakker, N. W., 1983a. Amsterdam Expeditions to the West Indian Islands, Report 24. The genus 
Heterocypris (Crustacea, Ostracoda) in the West Indies. Part II. Carapace length, ecology and zoogeography. Bijdr. Dierk., 53 (1): 115-134. , 1983b. Amsterdam Expeditions to the West Indian Islands, Report 25. The genus Hemicypris (Crustacea, Ostracoda) in the West Indies. Bijdr. Dierk., 53 (1): 135-157.

-, 1983 c. Amsterdam Expeditions to the West Indian Islands, Report 35. The genus Strandesia and other Cypricercini (Crustacea, Ostracoda) in the West Indies. Part I. Taxonomy. Bijdr. Dierk., 53 (2): 327-368.

Hummelinck, P. WagenaAr, 1940a. General information. Stud. Fauna Curaçao, 1 (1): 1-58.
Curaçao, 2 (4): 1-42.

- , 1953. Description of new localities. Stud. Fauna Curaçao, 4 (17): 1-108.

-, 1981 . Land and fresh-water localities. Stud. Fauna Curaçao, 63 (192): 1-133, pls. I-IL.

Sokal, R. R. F. J. RohlF, 1981. Biometry (2nd ed.): 1-859 (W. H. Freeman \& Co., San Francisco).

Stock, J. H., 1979. Amsterdam Expeditions to the West Indian Islands, Report 4. Station list. Verslagen technische Gegevens Inst. taxon. Zoöl. (Zoöl. Mus.) Univ. Amsterdam, 20: 1-78.

- , 1983. Predation as a factor influencing the occurrence and distribution of small Crustacea in West Indian groundwaters. Bijdr. Dierk., 53 (2): 233-243.

Received: 3 November 1983 
Appendix I

Station list with environmental data and data on carapace length of samples containing $S$. longula and/or $S$. stocki, taken in wells in Haiti, by the Amsterdam Expeditions to the West Indian Islands.

\begin{tabular}{|c|c|c|c|c|c|c|}
\hline Département (date) & \multirow{2}{*}{$\begin{array}{l}\text { Latitude } \\
\text { Longitude }\end{array}$} & \multirow{2}{*}{$\begin{array}{l}\text { Environmental data; } \\
\text { chlorinity }(\mathrm{mg} / \mathrm{l})\end{array}$} & \multicolumn{2}{|c|}{ Strandesia longula } & \multicolumn{2}{|c|}{ Strandesia stocki } \\
\hline $\begin{array}{l}\text { Station Locality } \\
\text { no. }\end{array}$ & & & $\begin{array}{l}N \text { of } \\
\text { speci- } \\
\text { mens }\end{array}$ & $\begin{array}{l}\text { mean length } \\
\pm \mathrm{S} . \mathrm{D} .(n) \\
\text { (length range) } \\
(\mathrm{mm})\end{array}$ & $\begin{array}{l}N \text { of } \\
\text { speci- } \\
\text { mens }\end{array}$ & $\begin{array}{l}\text { mean length } \\
\pm S . D .(n) \\
\text { (length range) } \\
\text { (mm) }\end{array}$ \\
\hline
\end{tabular}

Dépt. de l'Ouest (4 and 5-V-1978)

S 78/197 E. of Croix-des-Missions

$18^{\circ} 35^{\prime} 38^{\prime \prime} \mathrm{N}$
$72^{\circ} 16^{\prime} 55^{\prime \prime} \mathrm{W}$

$72^{\circ} 16^{\prime} 53^{\prime \prime} \mathrm{W}$

S 78/199 Just W. of S 78/198 $18^{\circ} 35^{\prime} 36^{\prime \prime} \mathrm{N}$

S 78/200 S. side of road N 102

S 78/201 Slightly S.W. of S 78/200

S 78/205 Between Gressin and

1206 Léogane

Ditto: Croix-des-Missions (9 and 10-XI-1979)

S 79/529 Brook Balisaille, where $18^{\circ} 32^{\prime} 40^{\prime \prime} \mathrm{N}$ it cuts the road Ganthier- $72^{\circ} 05^{\prime} 37^{\prime \prime} \mathrm{W}$ Croix-des-Bouquets

S 79/534 Well of Marcel Georges, $18^{\circ} 34^{\prime} 24^{\prime \prime} \mathrm{N}$ in Fleuriot $72^{\circ} 15^{\prime} 42^{\prime \prime} \mathrm{W}$

S 79/536 Well of Thérèse Celamy, $18^{\circ} 35^{\prime} 03^{\prime \prime} \mathrm{N}$ Groureau, Cazeau $72^{\circ} 16^{\prime} 23^{\prime \prime} \mathrm{W}$

S 79/538 Well of Macelon Saint $18^{\circ} 36^{\prime} 15^{\prime \prime} \mathrm{N}$ Germain, in Carrefour $\quad 7^{\circ} 17^{\prime} 03^{\prime \prime} \mathrm{W}$ Marin (Furgy = Fourgu)

S 79/539 Well of Gérard Gélan, in Marin

S 79/540 Well of Mrs. Antagras, Mifroh, $150 \mathrm{~m}$ from 539

S 79/541 Verdier Edouard's well, in Gibert

Dépt. du Sud-Est (Cayes-Jacmel) (5-V-1978)

S 78/213 Cayes-Jacmel, N. side $18^{\circ} 13^{\prime} 54^{\prime \prime} \mathrm{N}$ of road

S 78/214 Just W. of Marigot, S. side of road

S 78/215 Hamlet Raymond, Puits Conseil Communautaire

S 78/216 Jacmel, house of Dr. Abel Gousse $72^{\circ} 32^{\prime} 04^{\prime \prime} \mathrm{W}$

Ditto: (13-XI-1979)

S 79/547 Well of Mrs. André $18^{\circ} 13^{\prime} 58^{\prime \prime N}$ Pascal, at Massac $\quad 72^{\circ} 22^{\prime} 50^{\prime \prime} \mathrm{W}$

S 79/549 Well of Emile Magloire, $18^{\circ} 14^{\prime} 01$ ' N at $\mathrm{Ti}$ Mouillage $\quad{72^{\circ}}^{\circ} 22^{\prime} 26^{\prime \prime} \mathrm{W}$

S 79/550 Well of André Jules, $18^{\circ} 13^{\prime} 58^{\prime \prime} \mathrm{N}$ at Massac $72^{\circ} 22^{\prime} 50^{\prime \prime} \mathrm{W}$

S 79/551 Massac, well opposite $\quad 18^{\circ} 13^{\prime} 58^{\prime \prime} \mathrm{N}$ of $550 \quad 72^{\circ} 22^{\prime} 50^{\prime \prime} \mathrm{W}$

Ditto: Marigot (16-XI-1979)

S 79/560 Well of Jacques Simein, $18^{\circ} 13^{\prime} 51^{\prime \prime} \mathrm{N}$ at Marigot $72^{\circ} 18^{\prime} 52^{\prime \prime} \mathrm{W}$

S 79/561 Well of Vetirie Lapierre, $18^{\circ} 13^{\prime} 51^{\prime \prime} \mathrm{N}$ at Marigot $72^{\circ} 16^{\prime} 53^{\prime \prime} \mathrm{W}$

$18^{\circ} 36^{\prime} 31^{\prime \prime N}$ $72^{\circ} 17^{\prime} 31^{\prime \prime} \mathrm{W}$ $18^{\circ} 36^{\prime} 31^{\prime \prime} \mathrm{N}$ $72^{\circ} 17^{\prime} 31^{\prime \prime} \mathrm{W}$ $18^{\circ} 36^{\circ} 45^{\prime \prime} \mathrm{N}$ $72^{\circ} 18^{\prime} 11^{\prime \prime} \mathrm{W}$

$18^{\circ} 13^{\prime} 54^{\prime \prime} \mathrm{N}$
$72^{\circ} 23^{\prime} 50^{\prime \prime} \mathrm{W}$

$18^{\circ} 14^{\prime} 07^{\prime \prime N}$ $72^{\circ} 20^{\prime} 24^{\prime \prime} \mathrm{W}$ $18^{\circ} 13^{\prime} 30^{\prime \prime} \mathrm{N}$ $72^{\circ} 25^{\prime} 36^{\prime \prime} \mathrm{W}$

$18^{\circ} 14^{\prime} 31^{\prime \prime} \mathrm{N}$

dug hole in sand; 40

open, cement edge; 80

covered; 100

covered

open, in sand, clean; 10

open, in stone and black

soil; 40

fast running, gravel,much

moving sand; 36

dug in accretion of land,

covered; 47

open, dug in accretion of land; 18

open; 230

open, primitive; 310

open, primitive; 67

open, dug in muddy

ground; 57

open, clean; 40

open; 240

covered, fairly clean; 30

covered, neglected; 50

open, primitive; 38

open; 70

dug in the mud; 59

open; 51

$72^{\circ} 18^{\prime} 52^{\prime \prime} \mathrm{W}$ open, walled-in to the

bottom, clean; 31

open, walled-in, clean; 34
$1.32 \pm 0.03(41)$

$1.32 \pm 0.03(7)$

(1.26 to 1.36 )

5

-

$1-$

-

$1.55 \pm 0.05(81) \quad 33$

(1.47 to 1.69 )

$0.86 \pm 0.02(26)$

$(0.82$ to 0.90$)$

$(0.78$ to 0.84$)$

-

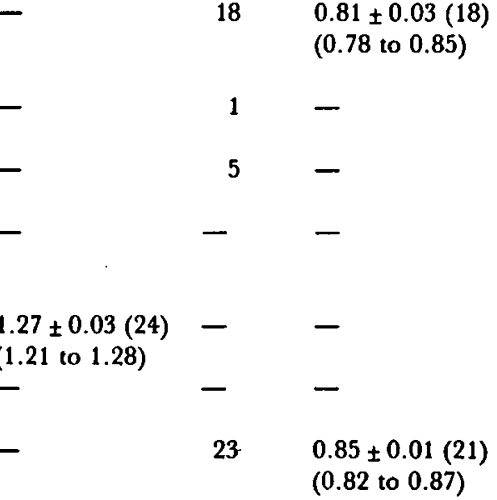

(0.82 to 0.87 )

60

$1.31 \pm 0.03(50)-$

(1.26 to 1.34 )

3

10

85

$1.21 \pm 0.04(31) \quad-\quad-$

(1.14 to 1.28 )

2

27

$1.24 \pm 0.03(16)$ (1.20 to 1.30$)$

60

$0.78 \pm 0.02(29)$

$(0.76$ to 0.81$)$ 
APPENDIX I (continued)

\begin{tabular}{|c|c|c|c|c|c|c|c|}
\hline \multicolumn{2}{|c|}{ Département (date) } & \multirow{2}{*}{$\begin{array}{l}\text { Latitude } \\
\text { Longitude }\end{array}$} & \multirow{2}{*}{$\begin{array}{l}\text { Environmental data; } \\
\text { chlorinity }(\mathrm{mg} / \mathrm{l})\end{array}$} & \multicolumn{2}{|c|}{ Strandesia longula } & \multicolumn{2}{|c|}{ Strandesia stocki } \\
\hline $\begin{array}{l}\text { Station } \\
\text { no. }\end{array}$ & Locality & & & $\begin{array}{l}N \text { of } \\
\text { speci- } \\
\text { mens }\end{array}$ & $\begin{array}{l}\text { mean length } \\
\pm \mathrm{S} . \mathrm{D} .(n) \\
\text { (length range) } \\
(\mathrm{mm})\end{array}$ & $\begin{array}{l}N \text { of } \\
\text { speci- } \\
\text { mens }\end{array}$ & $\begin{array}{l}\text { mean length } \\
\pm \text { S.D. ( } n) \\
\text { (length range) } \\
(\mathrm{mm})\end{array}$ \\
\hline S $79 / 562$ & $\begin{array}{l}\text { Agricultural well Sévrin, } \\
\text { at Marigot }\end{array}$ & $\begin{array}{l}18^{\circ} 13^{\prime} 48^{\prime \prime} \mathrm{N} \\
72^{\circ} 19^{\prime} 16^{\prime \prime} \mathrm{W}\end{array}$ & $\begin{array}{l}\text { open, walled-in to the } \\
\text { bottom, clean; } 150\end{array}$ & 33 & $\begin{array}{l}1.28 \pm 0.03(14) \\
(1.23 \text { to } 1.33)\end{array}$ & 7 & - \\
\hline S $79 / 564$ & $\begin{array}{l}\text { Well of Ferilys Byssaints, } \\
\text { at Marigot }\end{array}$ & $\begin{array}{l}18^{\circ} 13^{\prime} 48^{\prime \prime} \mathrm{N} \\
72^{\circ} 19^{\prime} 16^{\prime \prime} \mathrm{W}\end{array}$ & $\begin{array}{l}\text { open, neglected, sand } \\
\text { and debris; } 26\end{array}$ & 8 & - & 3 & - \\
\hline S $79 / 565$ & $\begin{array}{l}\text { Well of the Rectory, } \\
\text { at Marigot }\end{array}$ & $\begin{array}{l}18^{\circ} 14^{\prime} 01^{\prime \prime} \mathrm{N} \\
72^{\circ} 19^{\prime} 33^{\prime \prime} \mathrm{W}\end{array}$ & $\begin{array}{l}\text { covered; walled-in to the } \\
\text { bottom; } 280\end{array}$ & 1 & - & 1 & - \\
\hline S $79 / 566$ & $\begin{array}{l}\text { Well opposite the } \\
\text { barracks, at Marigot }\end{array}$ & $\begin{array}{l}18^{\circ} 13^{\prime} 51^{\prime \prime} \mathrm{N} \\
72^{\circ} 19^{\prime} 43^{\prime \prime} \mathrm{W}\end{array}$ & $\begin{array}{l}\text { open, walled-in to the } \\
\text { bottom; } 90\end{array}$ & 1 & - & 32 & $\begin{array}{l}0.82 \pm 0.02(23) \\
(0.78 \text { to } 0.84)\end{array}$ \\
\hline S 79/567 & $\begin{array}{l}\text { Well of Lucius René, } \\
\text { at Marigot (W.) }\end{array}$ & $\begin{array}{l}18^{\circ} 13^{\prime} 51^{\prime \prime} \mathrm{N} \\
72^{\circ} 19^{\prime} 43^{\prime \prime} \mathrm{W}\end{array}$ & $\begin{array}{l}\text { open, completely walled- } \\
\text { in, clean; } 68\end{array}$ & 21 & - & 15 & $(0.81$ to 0.86$)(6)$ \\
\hline S $79 / 568$ & $\begin{array}{l}\text { Well in a park, at } \\
\text { Marigot (W.) }\end{array}$ & $\begin{array}{l}18^{\circ} 13^{\prime} 51^{\prime \prime N} \\
71^{\circ} 19^{\prime} 43^{\prime \prime} \mathrm{W}\end{array}$ & open; 61 & 22 & $\overrightarrow{(1.10}$ to 1.22$)$ & 400 & $\begin{array}{l}0.79 \pm 0.02(45) \\
(0.76 \text { to } 0.82)\end{array}$ \\
\hline \multicolumn{8}{|c|}{ Dépt. de l'Artibonite (8-V-1978) } \\
\hline S $78 / 231$ & $\begin{array}{l}\text { Passe Reine (N.E. of } \\
\text { Gonaïves) }\end{array}$ & $\begin{array}{l}19^{\circ} 30^{\prime} 29^{\prime \prime} \mathrm{N} \\
72^{\circ} 32^{\prime} 38^{\prime \prime} \mathrm{W}\end{array}$ & $\begin{array}{l}\text { covered, clean, in } \\
\text { alluvial deposits; } 840\end{array}$ & - & - & 30 & $\begin{array}{l}0.80 \pm 0.02(22) \\
(0.78 \text { to } 0.84)\end{array}$ \\
\hline S $78 / 242$ & $\begin{array}{l}\text { Just E.S.E. of Gonaïves, } \\
\text { S. side of road D } 100\end{array}$ & $\begin{array}{l}19^{\circ} 26^{\prime} 28^{\prime \prime N} \\
72^{\circ} 40^{\prime} 57^{\prime \prime W}\end{array}$ & $\begin{array}{l}\text { open, with windpump; } \\
150\end{array}$ & - & - & 7 & - \\
\hline \multicolumn{8}{|c|}{ Ditto: (21, 22 and 24-XI-1979) } \\
\hline S $79 / 591$ & $\begin{array}{l}\text { Well Frank Mezidor, } \\
\text { S. of Saint-Marc }\end{array}$ & $\begin{array}{l}19^{\circ} 05^{\prime} 29^{\prime \prime} \mathrm{N} \\
72^{\circ} 42^{\prime} 04^{\prime \prime} \mathrm{W}\end{array}$ & $\begin{array}{l}\text { covered, muddy, in } \\
\text { sand; } 45\end{array}$ & - & - & 6 & - \\
\hline S 79/592 & $\begin{array}{l}\text { Well Tubérisse Surpris, } \\
\text { at Saint-Marc }\end{array}$ & $\begin{array}{l}19^{\circ} 05^{\prime} 29^{\prime \prime} \mathrm{N} \\
72^{\circ} 42^{\prime} 04^{\prime \prime} \mathrm{W}\end{array}$ & covered, in sand; 24 & - & - & 47 & $\begin{array}{l}0.83 \pm 0.02(47) \\
(0.77 \text { to } 0.86)\end{array}$ \\
\hline S $79 / 597$ & $\begin{array}{l}\text { Well "Portail des } \\
\text { Guêpes", at Saint-Marc }\end{array}$ & $\begin{array}{l}19^{\circ} 07^{\prime} 23^{\prime \prime N} \\
72^{\circ} 41^{\prime} 44^{\prime \prime} \mathrm{W}\end{array}$ & $\begin{array}{l}\text { open, made in limestone; } \\
230\end{array}$ & - & - & 52 & $\begin{array}{l}0.85 \pm 0.02(39) \\
(0.82 \text { to } 0.89)\end{array}$ \\
\hline S $79 / 599$ & $\begin{array}{l}\text { Well of the Night Club, } \\
\text { N. of Saint-Marc }\end{array}$ & $\begin{array}{l}19^{\circ} 07^{\prime} 23^{\prime \prime N} \\
72^{\circ} 41^{\prime} 44^{\prime \prime} \mathrm{W}\end{array}$ & $\begin{array}{l}\text { open, walled-in to the } \\
\text { bottom; } 180\end{array}$ & - & - & 75 & $\begin{array}{l}0.86 \pm 0.02(45) \\
(0.79 \text { to } 0.90)\end{array}$ \\
\hline S $79 / 600$ & $\begin{array}{l}\text { Well of Maître Graviel } \\
\text { Martel, N. of Saint-Marc }\end{array}$ & $\begin{array}{l}19^{\circ} 07^{\prime} 23^{\prime \prime} \mathrm{N} \\
72^{\circ} 41^{\prime} 44^{\prime \prime} \mathrm{W}\end{array}$ & $\begin{array}{l}\text { open, partly walled-in; } \\
66\end{array}$ & - & - & 220 & lost \\
\hline S $79 / 617$ & $\begin{array}{l}\text { Well near market of } \\
\text { Arcahaie }\end{array}$ & $\begin{array}{l}18^{\circ} 46^{\prime} 08^{\prime \prime} \mathrm{N} \\
72^{\circ} 30^{\prime} 44^{\prime \prime} \mathrm{W}\end{array}$ & $\begin{array}{l}\text { open, troubled water; } \\
145\end{array}$ & 180 & $\begin{array}{l}1.28 \pm 0.05(91) \\
(1.17 \text { to } 1.14)\end{array}$ & - & - \\
\hline S $79 / 618$ & $\begin{array}{l}\text { Well of Luc Pierre, at } \\
\text { Arcahaie, Rue Abbé } \\
\text { Andelin }\end{array}$ & $\begin{array}{l}18^{\circ} 46^{\prime} 08^{\prime \prime} \mathrm{N} \\
72^{\circ} 30^{\prime} 44^{\prime \prime} \mathrm{W}\end{array}$ & $\begin{array}{l}\text { open, walled-in till water } \\
\text { level, clean; } 100\end{array}$ & 2 & - & - & - \\
\hline S $79 / 620$ & $\begin{array}{l}\text { Well of Boss Raoul } \\
\text { Bélizaire, at Arcahaie } \\
\text { (district Cortade) }\end{array}$ & - & $\begin{array}{l}\text { open, made in sand, } \\
\text { clean; } 17\end{array}$ & - & - & 12 & $\begin{array}{l}0.84 \pm 0.02(10) \\
(0.79 \text { to } 0.87)\end{array}$ \\
\hline \multicolumn{8}{|c|}{ Dépt. du Centre (28-XI-1979) } \\
\hline S $79 / 630$ & $\begin{array}{l}\text { "Source Tête Nègre", } \\
\text { E. of Mirebalais (road } \\
\text { to Lascehobas) }\end{array}$ & $\begin{array}{l}18^{\circ} 49^{\prime} 40^{\prime \prime} \mathrm{N} \\
72^{\circ} 05^{\prime} 06^{\prime \prime} \mathrm{W}\end{array}$ & $\begin{array}{l}\text { spring interstitia, water } \\
\text { almost stagnant; } 23\end{array}$ & - & - & 10 & $\overline{(0.83}$ to 0.86$)(7)$ \\
\hline \multicolumn{8}{|c|}{ Dépt. de Grande Anse (2 and 5-XII-1979) } \\
\hline S $79 / 647$ & $\begin{array}{l}\text { Well of Anacius François, } \\
\text { at Gomier }\end{array}$ & $\begin{array}{l}18^{\circ} 36^{\prime} 15^{\prime \prime} \mathrm{N} \\
74^{\circ} 04^{\prime} 10^{\prime \prime} \mathrm{W}\end{array}$ & $\begin{array}{l}\text { walled-in to water level, } \\
\text { clear; } 125\end{array}$ & - & - & 20 & $\begin{array}{l}0.82 \pm 0.02(16) \\
(0.79 \text { to } 0.85)\end{array}$ \\
\hline S $79 / 658$ & $\begin{array}{l}\text { Limnocrene spring, at } \\
\text { Beaucalin }\end{array}$ & $\begin{array}{l}18^{\circ} 35^{\prime} 36^{\prime \prime N} \\
74^{\circ} 11^{\prime} 57^{\prime \prime} \mathrm{W}\end{array}$ & not karstified; 18 & 52 & $\begin{array}{l}1.31 \pm 0.03(26) \\
(1.25 \text { to } 1.37)\end{array}$ & 4 & - \\
\hline \multicolumn{8}{|c|}{ Dépt. du Nord (9 and 10-V-1978) } \\
\hline S $78 / 234$ & $\begin{array}{l}\text { Plage Diquoi (N.W. of } \\
\text { Cap Haïtien) }\end{array}$ & $\begin{array}{l}19^{\circ} 46^{\prime} 50^{\prime \prime} \mathrm{N} \\
72^{\circ} 14^{\prime} 43^{\prime \prime} \mathrm{W}\end{array}$ & $\begin{array}{l}\text { open, clean, foot of } \\
\text { cliff; } 760\end{array}$ & 4 & - & 12 & - \\
\hline S $78 / 235$ & $\begin{array}{l}\text { Slightly S.W. of } \\
\text { S 78/234 }\end{array}$ & $\begin{array}{l}19^{\circ} 46^{\prime} 34^{\prime \prime} \mathrm{N} \\
72^{\circ} 14^{\prime} 39^{\prime \prime} \mathrm{W}\end{array}$ & $\begin{array}{l}\text { water colour gray, in } \\
\text { limestone rock; } 1320\end{array}$ & 1 & - & 10 & $\begin{array}{l}0.86 \pm 0.02(9) \\
(0.83 \text { to } 0.89)\end{array}$ \\
\hline S $78 / 236$ & $\begin{array}{l}\text { N. E. of Cormier-Plage } \\
60 \mathrm{~m} \text { from the sea }\end{array}$ & $\begin{array}{l}19^{\circ} 46^{\prime} 13^{\prime \prime N} \\
72^{\circ} 14^{\prime} 51^{\prime \prime} \mathrm{W}\end{array}$ & $\begin{array}{l}\text { open, } \mathrm{H}_{2} \mathrm{~S} \text {, in alluvial } \\
\text { plain; } 3320\end{array}$ & - & - & 10 & $\begin{array}{l}0.91 \pm 0.02(10) \\
(0.89 \text { to } 0.94)\end{array}$ \\
\hline S $78 / 237$ & $\begin{array}{l}\text { Village of Lombard } \\
\text { (just } \mathbf{E} \text {. of Limbé), } \\
\text { S. side of road D } 100\end{array}$ & $\begin{array}{l}19^{\circ} 41^{\prime} 57^{\prime \prime} \mathrm{N} \\
72^{\circ} 22^{\prime} 28^{\prime \prime} \mathrm{W}\end{array}$ & $\begin{array}{l}\text { open, filamentous algae; } \\
160\end{array}$ & - & - & 53 & $\begin{array}{l}0.77 \pm 0.01(29) \\
(0.76 \text { to } 0.79)\end{array}$ \\
\hline
\end{tabular}


APPENDIX I (continued)

\begin{tabular}{|c|c|c|c|c|c|c|c|}
\hline \multicolumn{2}{|c|}{ Département (date) } & \multirow{2}{*}{$\begin{array}{l}\text { Latitude } \\
\text { Longitude }\end{array}$} & \multirow{2}{*}{$\begin{array}{l}\text { Environmental data; } \\
\text { chlorinity }(\mathrm{mg} / \mathrm{l})\end{array}$} & \multicolumn{2}{|c|}{ Strandesia longula } & \multicolumn{2}{|c|}{ Strandesia stocki } \\
\hline $\begin{array}{l}\text { Station } \\
\text { no. }\end{array}$ & Locality & & & $\begin{array}{l}N \text { of } \\
\text { speci- } \\
\text { mens }\end{array}$ & $\begin{array}{l}\text { mean length } \\
\pm \text { S.D. }(n) \\
\text { (length range) } \\
(\mathrm{mm})\end{array}$ & $\begin{array}{l}N \text { of } \\
\text { speci- } \\
\text { mens }\end{array}$ & $\begin{array}{l}\text { mean length } \\
\pm \text { S.D. }(n) \\
\text { (length range) } \\
(\mathrm{mm})\end{array}$ \\
\hline S $78 / 239$ & $\begin{array}{l}\text { Limbé, S. side of road } \\
\text { D } 100\end{array}$ & $\begin{array}{l}19^{\circ} 42^{\prime} 05^{\prime \prime} \mathrm{N} \\
72^{\circ} 23^{\prime} 53^{\prime \prime} \mathrm{W}\end{array}$ & open; 100 & - & - & 48 & $\begin{array}{l}0.82 \pm 0.04(18) \\
(0.78 \text { to } 0.89)\end{array}$ \\
\hline S $78 / 240$ & Near S 78/239 & as $\mathrm{S} 78 / 239$ & covered; 240 & - & - & 200 & $\begin{array}{l}0.80 \pm 0.02(35) \\
(0.78 \text { to } 0.83)\end{array}$ \\
\hline \multicolumn{8}{|c|}{ Ditto: S.E. of Milot (10-XII-1979) } \\
\hline S $79 / 676$ & $\begin{array}{l}\text { Well of Raphael Saint- } \\
\text { frère at Bénard }\end{array}$ & $\begin{array}{l}\text { ca. } 19^{\circ} 38^{\prime} \mathrm{N} \\
\text { ca. } 72^{\circ} 12^{\prime} \mathrm{W}\end{array}$ & $\begin{array}{l}\text { walled-in to the middle, } \\
\text { grey sediment; } 385\end{array}$ & 11 & $\begin{array}{l}1.34 \pm 0.02(11) \\
(1.30 \text { to } 1.36)\end{array}$ & 1 & - \\
\hline S $79 / 677$ & $\begin{array}{l}\text { Well of Verne Exalus at } \\
\text { Barrière Battant }\end{array}$ & $\begin{array}{l}19^{\circ} 37^{\prime} 13^{\prime \prime} \mathrm{N} \\
72^{\circ} 11^{\prime} 01^{\prime \prime} \mathrm{W}\end{array}$ & $\begin{array}{l}\text { walled-in to the bottom; } \\
64\end{array}$ & 120 & $\begin{array}{l}1.39 \pm 0.05(56) \\
(1.33 \text { to } 1.55)\end{array}$ & 125 & $\begin{array}{l}0.83 \pm 0.02(50) \\
(0.81 \text { to } 0.89)\end{array}$ \\
\hline S $79 / 678$ & $\begin{array}{l}\text { Well of "Deshornmes } \\
\text { Salvant", at Tassy }\end{array}$ & $\begin{array}{l}\text { ca. } 19^{\circ} 36^{\prime} \mathrm{N} \\
\text { ca. } 72^{\circ} 12^{\prime} \mathrm{W}\end{array}$ & $\begin{array}{l}\text { covered, walled-in to } \\
\text { water level; } 31\end{array}$ & 18 & $\begin{array}{l}1.38 \pm 0.04(10) \\
(1.33 \text { to } 1.46)\end{array}$ & 32 & $\begin{array}{l}0.81 \pm 0.03(32) \\
(0.77 \text { to } 0.85)\end{array}$ \\
\hline S $79 / 679$ & $\begin{array}{l}\text { Well of Narcius Etienne, } \\
\text { at Brossard }\end{array}$ & $\begin{array}{l}\text { ca. } 19^{\circ} 36^{\prime} \mathrm{N} \\
\text { ca. } 72^{\circ} 12^{\prime} \mathrm{W}\end{array}$ & abandoned; 60 & 3 & - & 20 & $\begin{array}{l}0.82 \pm 0.02(16) \\
(0.79 \text { to } 0.85)\end{array}$ \\
\hline S $79 / 680$ & $\begin{array}{l}\text { Public well at Lécurie } \\
\text { (Milot) }\end{array}$ & $\begin{array}{l}\text { ca. } 19^{\circ} 36^{\prime} \mathrm{N} \\
\text { ca. } 72^{\circ} 12^{\prime} \mathrm{W}\end{array}$ & $\begin{array}{l}\text { walled-in to the bottom, } \\
\text { much sediment; } 45\end{array}$ & 1 & - & - & - \\
\hline \multicolumn{8}{|c|}{ Ditto: E. of Limbé (10 and 11-XII-1979) } \\
\hline S $79 / 681$ & $\begin{array}{l}\text { Well of Mrs. Elitesse } \\
\text { Jeanlouis, at Lombard }\end{array}$ & $\begin{array}{l}19^{\circ} 42^{\prime} 23^{\prime \prime} \mathrm{N} \\
72^{\circ} 23^{\prime} 08^{\prime \prime} \mathrm{W}\end{array}$ & $\begin{array}{l}\text { walled-in to the bottom; } \\
69\end{array}$ & - & - & 250 & $\begin{array}{l}0.83 \pm 0.02(53) \\
(0.81 \text { to } 0.85)\end{array}$ \\
\hline S $79 / 682$ & $\begin{array}{l}\text { Well of Mrs. Gaspard } \\
\text { Caséix, at Lombard }\end{array}$ & $\begin{array}{l}19^{\circ} 42^{\prime} 23^{\prime \prime} \mathrm{N} \\
72^{\circ} 23^{\prime} 08^{\prime \prime} \mathrm{W}\end{array}$ & $\begin{array}{l}\text { walled-in to the bottom; } \\
100\end{array}$ & - & - & 45 & $\begin{array}{l}0.82 \pm 0.02(24) \\
(0.79 \text { to } 0.85)\end{array}$ \\
\hline S $79 / 683$ & $\begin{array}{l}\text { Well of Francéis, at } \\
\text { Limbé }\end{array}$ & $\begin{array}{l}19^{\circ} 42^{\prime} 14^{\prime \prime} \mathrm{N} \\
72^{\circ} 23^{\prime} 55^{\prime \prime} \mathrm{W}\end{array}$ & $\begin{array}{l}\text { open, walled-in to the } \\
\text { water level, dirty; } 32\end{array}$ & - & - & 10 & $\begin{array}{l}0.82 \pm 0.03(10) \\
(0.79 \text { to } 0.87)\end{array}$ \\
\hline S $79 / 688$ & $\begin{array}{l}\text { Well Mézardié (in ham- } \\
\text { let Moulin de Limbé) }\end{array}$ & $\begin{array}{l}19^{\circ} 42^{\prime} 14^{\prime \prime} \mathrm{N} \\
72^{\circ} 23^{\prime} 55^{\prime \prime} \mathrm{W}\end{array}$ & $\begin{array}{l}\text { walled-in, very dirty; } \\
12\end{array}$ & - & - & 85 & $\begin{array}{l}0.84 \pm 0.02(57) \\
(0.81 \text { to } 0.89)\end{array}$ \\
\hline S 79/689 & The Rectory at Limbé & $\begin{array}{l}19^{\circ} 42^{\prime} 14^{\prime \prime} \mathrm{N} \\
72^{\circ} 23^{\prime} 55^{\prime \prime} \mathrm{W}\end{array}$ & $\begin{array}{l}\text { covered, clean, sandy } \\
\text { bottom, electr. pump; } 14\end{array}$ & - & - & 10 & $\begin{array}{l}0.85 \pm 0.03(10) \\
(0.81 \text { to } 0.87)\end{array}$ \\
\hline
\end{tabular}




\section{APPENDIX II}

Station list with environmental data and data on carapace length of samples containing $S$. longula, taken on the Lesser Antilles, Grand Cayman, Providenciales, and the Bahamas, by the Amsterdam Expeditions to the West Indian Islands.

\begin{tabular}{|c|c|c|c|c|c|c|}
\hline $\begin{array}{l}\text { Island } \\
\text { Station }\end{array}$ & Locality & $\begin{array}{l}\text { Latitude } \\
\text { Longitude }\end{array}$ & $\begin{array}{l}\text { Environmental } \\
\text { data }\end{array}$ & $\begin{array}{l}\text { Chlo- } \\
\text { rinity } \\
(\mathrm{mg} / \mathrm{l})\end{array}$ & $\begin{array}{l}N \text { of } \\
\text { speci- } \\
\text { mens }\end{array}$ & $\begin{array}{l}\text { Carapace }(\mathrm{mm}) \text { : } \\
\text { mean length } \\
\pm S . D . \text { ( } n) \\
\text { (length range) }\end{array}$ \\
\hline
\end{tabular}

ST. MARTIN

S 76/41 Anse des Pères, French side, well (18-VI-1976)

S 82/142 Jones Gut, between Orléans and Cul de Sac; pool (29-I-1982)

ST. EUSTATIUS (19-VI-1976)

S 76/44 Schotsenhoek; well with ruined windpump

S 76/49 Rooi (= gully) Spouts, near Zeelandia; well

TORTOLA (25 and 26-IV-1978)

S 78/139 Chapel Hill; well with troughs

S 78/151 Long Bay Point; well near the sea

S 78/152 E.N.E. of Havers, N. side of road; well near ruined farm

CULEBRA (2-V-1978)

S 78/189 Puerto del Manglar; overshadowed well

$18^{\circ} 18^{\prime} 41^{\prime \prime} \mathrm{N}$ open, round $65^{\circ} 15^{\prime} 42^{\prime \prime W}$

$17^{\circ} 29^{\prime} 06^{\prime \prime N}$ $62^{\circ} 58^{\prime} 58^{\prime \prime} \mathrm{W}$

$17^{\circ} 30^{\prime} 11^{\prime \prime N}$

$62^{\circ} 58^{\prime} 39^{\prime \prime} \mathrm{W}$

round, covered

open, rather clean

round

pool in bed of

dry torrent

$500 \quad 38$

$1.29 \pm 0.02(38)$

$18^{\circ} 05^{\prime} 10^{\prime \prime} \mathrm{N}$

$63^{\circ} 01^{\prime} 36^{\prime \prime} \mathrm{W}$

open, rather clean

-

17

$1.20 \pm 0.04(14)$

$450 \quad 38$

(1.13 to 1.26 )

$1.29 \pm 0.04(23)$

(1.23 to 1.37 )

$18^{\circ} 26^{\prime} 30^{\prime \prime} \mathrm{N}$ open, fairly clean

$64^{\circ} 33^{\prime} 25^{\prime \prime} \mathrm{W}$

$18^{\circ} 23^{\prime} 57^{\prime \prime} \mathrm{N}$

$64^{\circ} 41^{\prime} 11^{\prime \prime} \mathrm{W}$

$18^{\circ} 23^{\prime} 54^{\prime \prime} \mathrm{N}$

$64^{\circ} 38^{\prime} 22^{\prime \prime} \mathrm{W}$

open, clean

partly covered

880

$-\quad 58$

920

12

$1.22 \pm 0.04(42)$

(1.18 to 1.29 )

$1.19 \pm 0.05(12)$

(1.15 to 1.33 )

1390

$19^{\circ} 22^{\prime} 22^{\prime \prime} \mathrm{N}$

$81^{\circ} 24^{\prime} 17^{\prime \prime} \mathrm{W}$

$19^{\circ} 22^{\prime} 35^{\prime \prime N}$

$81^{\circ} 24^{\prime} 19^{\prime \prime} \mathrm{W}$

open shaft in lime-

stone

covered, in coral

rock (with brooklet) well

PROVIDENCIALES (16-XI-1979)

S 79/149 Pasture well, East

$21^{\circ} 47^{\prime} 11^{\prime \prime N}$

$72^{\circ} 15^{\prime} 43^{\prime \prime} \mathrm{W}$

open

2815

20

17

$22^{\circ} 22^{\prime} 14^{\prime \prime} \mathrm{N}$ cut in rock, with

$72^{\circ} 57^{\prime} 52^{\prime \prime} \mathrm{W}$ square opening

$22^{\circ} 22^{\prime} 12^{\prime \prime} \mathrm{N}$ open, cut in rock

$72^{\circ} 57^{\prime} 53^{\prime \prime} \mathrm{W}$

$22^{\circ} 24^{\prime} 49^{\prime \prime} \mathrm{N}$

$73^{\circ} 07^{\prime} 35^{\prime \prime W}$

$22^{\circ} 25^{\prime} 45^{\prime \prime N}$

$73^{\circ} 05^{\prime} 45^{\prime \prime W}$

$22^{\circ} 25^{\prime} 46^{\prime \prime} \mathrm{N}$

$73^{\circ} 05^{\prime} 47^{\prime \prime} \mathrm{W}$

$22^{\circ} 25^{\prime} 48^{\prime \prime} \mathrm{N}$

$73^{\circ} 05^{\prime} 49^{\prime \prime} \mathrm{W}$

$22^{\circ} 25^{\prime} 44^{\prime \prime} \mathrm{N}$

$73^{\circ} 05^{\prime} 33^{\prime \prime} \mathrm{W}$ small openings; in

swamp (rain)land

open, water not

clear

half covered

square opening on

oval hole

open, oval opening
1120

140

150

1150

2110

1045

2680
(1.28 to 1.33$)$

$1.31 \pm 0.04(19)$

(1.23 to 1.37 )

$$
1
$$

56

$1.20 \pm 0.04(27)$

(1.15 to 1.29 )
S 79/135 Lower Pirate Well, Ebanozar Johnson's well $73^{\circ} 05^{\prime} 33^{\prime \prime}$ 
APPENDIX II (continued)

\begin{tabular}{|c|c|c|c|c|c|c|}
\hline $\begin{array}{l}\text { Island } \\
\text { Station }\end{array}$ & Locality & $\begin{array}{l}\text { Latitude } \\
\text { Longitude }\end{array}$ & $\begin{array}{l}\text { Environmental } \\
\text { data }\end{array}$ & $\begin{array}{l}\text { Chlo- } \\
\text { rinity } \\
\text { (mg/l) }\end{array}$ & $\begin{array}{l}N \text { of } \\
\text { speci- } \\
\text { mens }\end{array}$ & $\begin{array}{l}\text { Carapace }(\mathrm{mm}) \text { : } \\
\text { mean length } \\
\pm \text { S.D. }(n) \\
\text { (length range) }\end{array}$ \\
\hline
\end{tabular}

CROOKED ISLAND (27 and 28-XI-1979)

$\begin{array}{llll}\text { S 79/192 } & \text { Moss Town, well W. of } & 22^{\circ} 48^{\prime} 27^{\prime \prime N} & \text { open } \\ & \text { main road } & 74^{\circ} 15^{\prime} 25^{\prime \prime} \mathrm{W} & \\ \text { S 79/194 } & \text { Cripple Hill, well } & 22^{\circ} 47^{\prime} 55^{\prime \prime} \mathrm{N} & \text { open } \\ & & 7^{\circ} 14^{\prime} 35^{\prime \prime} \mathrm{W} & \\ \text { S 79/195 } & \text { Fair Field, well } & 22^{\circ} 47^{\prime} 14^{\prime \prime} \mathrm{N} & \text { open } \\ & & 74^{\circ} 13^{\prime} 39^{\prime \prime} \mathrm{W} & \\ \text { S 79/196 } & \text { Timber Hill, well } & 22^{\circ} 46^{\prime} 21^{\prime \prime} \mathrm{N} & \text { covered, with } \\ & & 74^{\circ} 12^{\prime} 15^{\prime \prime} \mathrm{W} & \text { square opening } \\ \text { S 79/197 } & \text { Cabbage Hill, public well } & 22^{\circ} 45^{\prime} 52^{\prime \prime} \mathrm{N} & \text { covered, square } \\ & & 74^{\circ} 13^{\prime} 13^{\prime \prime} \mathrm{W} & \text { opening, hand pump } \\ \text { S 79/198 } & \text { Cabbage Hill, Johnny Hill } & 22^{\circ} 45^{\prime} 56^{\prime \prime} \mathrm{N} & \text { circular, with } \\ & \text { section, well } & 74^{\circ} 13^{\prime} 28^{\prime \prime} \mathrm{W} & \text { oblong opening } \\ \text { S 79/199 } & \text { Cabbage Hill (South), well } & 22^{\circ} 45^{\prime} 46^{\prime \prime} \mathrm{N} & \text { covered, square } \\ & & 74^{\circ} 13^{\prime} 21^{\prime \prime} \mathrm{W} & \text { opening } \\ \text { S 79/202 } & \text { Boats' well } & 22^{\circ} 45^{\prime} 29^{\prime \prime} \mathrm{N} & \text { covered, square } \\ & & 74^{\circ} 11^{\prime} 51^{\prime \prime} \mathrm{W} & \text { opening } \\ \text { S 79/203 } & \text { Mayors Cay, public well } & 22^{\circ} 43^{\prime} 50^{\prime \prime} \mathrm{N} & \text { covered, oblong } \\ & & 74^{\circ} 09^{\prime} 25^{\prime \prime} \mathrm{W} & \text { opening } \\ \text { S 79/210 } & \text { True Blue (East), well } & 22^{\circ} 43^{\prime} 45^{\prime \prime} \mathrm{N} & \text { open, oblong } \\ & & 74^{\circ} 03^{\prime} 21^{\prime \prime} \mathrm{W} & \text { opening }\end{array}$

SAN SALVADOR (23 and 24-XI-1979)

S 79/183 United Estates Settlement, well

S 79/184 Hannah Bay, near Club Short Stop, well

S 79/187 Public well, S. of Bonefish Bay

S 79/189 Olympic Flame, Monument well

S 79/190 Sugar Loaf Settlement, well

S 79/191 Sandy Point Estate, W. of the Queens Highroad, well

ELEUTHERA (8 and 9-XI-1979)

S 79/96 Rock Sound Internationa Airport, N. side of W. end, well

S 79/98 John Millars (village), S. of John Millars Road, well

S 79/99 N. side of Bannerman Town, in front of Town School, well

S 79/100 The Village, two wells on T-crossing, S. boundary of village

$24^{\circ} 06^{\prime} 20^{\prime \prime} \mathrm{N}$

$74^{\circ} 27^{\prime} 09^{\prime \prime} \mathrm{W}$

$24^{\circ} 06^{\prime} 40^{\prime \prime} \mathrm{N}$

$74^{\circ} 27^{\prime} 08^{\prime \prime} \mathrm{W}$

$24^{\circ} 04^{\prime} 26^{\prime \prime} \mathrm{N}$

$74^{\circ} 31^{\prime} 44^{\prime \prime} \mathrm{W}$

$24^{\circ} 00^{\prime} 44^{\prime \prime N}$

$74^{\circ} 31^{\prime} 35^{\prime \prime} \mathrm{W}$

$24^{\circ} 00^{\prime} 03^{\prime \prime} \mathrm{N}$

$74^{\circ} 31^{\prime} 49^{\prime \prime} \mathrm{W}$

$23^{\circ} 57^{\prime} 23^{\prime \prime} \mathrm{N}$

$74^{\circ} 32^{\prime} 49^{\prime \prime} \mathrm{W}$

$24^{\circ} 53^{\prime} 37^{\prime \prime} \mathrm{N}$ covered with

$76^{\circ} 10^{\prime} 36^{\prime \prime} \mathrm{W}$

$24^{\circ} 41^{\prime} 07^{\prime \prime} \mathrm{N}$ open well, on the

$76^{\circ} 12^{\prime} 08^{\prime \prime} \mathrm{W}$ bank of larger pool

$24^{\circ} 38^{\prime} 22^{\prime \prime} \mathrm{N}$

$76^{\circ} 10^{\prime} 21^{\prime \prime W}$

$24^{\circ} 42^{\prime} 48^{\prime \prime} \mathrm{N}$ half covered, on

$76^{\circ} 12^{\prime} 58^{\prime \prime} \mathrm{W}$

$\begin{array}{ll}\text { S 79/101 } & \begin{array}{l}\text { Foxhill, W. of road near } \\ \text { house under construction, well }\end{array} \\ \text { S 79/102 } & \text { Waterford Settlement, near }\end{array}$

$24^{\circ} 43^{\prime} 12^{\prime \prime} \mathrm{N}$

$\begin{array}{ll}\text { S 79/101 } & \begin{array}{l}\text { Foxhill, W. of road near } \\ \text { house under construction, well }\end{array} \\ \text { S 79/102 } & \text { Waterford Settlement, near }\end{array}$ house, well

$76^{\circ} 13^{\prime} 06^{\prime \prime} \mathrm{W}$

$24^{\circ} 03^{\prime} 47^{\prime \prime} \mathrm{N}$ covered, square

$76^{\circ} 14^{\prime} 02^{\prime \prime} \mathrm{W}$ entrance open

open well, ruined

pump

open

covered, square

opening

open, square

opening

open, square

opening

concrete, square

entrance covered, square entrance, rubbish

\begin{tabular}{|c|c|c|}
\hline 310 & 4 & - \\
\hline 235 & 28 & $\begin{array}{l}1.17 \pm 0.04(14) \\
(1.12 \text { to } 1.23)\end{array}$ \\
\hline 420 & 73 & $\begin{array}{l}1.19 \pm 0.03(20) \\
(1.12 \text { to } 1.23)\end{array}$ \\
\hline 490 & 22 & $\begin{array}{l}1.21 \pm 0.06(11) \\
(1.10 \text { to } 1.29)\end{array}$ \\
\hline 130 & 2 & - \\
\hline 155 & 15 & $\begin{array}{l}1.18 \pm 0.03(11) \\
(1.12 \text { to } 1.23)\end{array}$ \\
\hline 45 & 5 & - \\
\hline 200 & 5 & $\overline{(1.10}$ to 1.14$)$ \\
\hline 180 & 2 & - \\
\hline 215 & 10 & $\begin{array}{l}1.19 \pm 0.06(9) \\
(1.10 \text { to } 1.26)\end{array}$ \\
\hline 545 & 3 & - \\
\hline 90 & 2 & - \\
\hline 45 & 51 & $\begin{array}{l}1.15 \pm 0.04(13) \\
(1.11 \text { to } 1.22)\end{array}$ \\
\hline 60 & 14 & - \\
\hline 140 & 35 & $\begin{array}{l}1.22 \pm 0.03(24) \\
(1.17 \text { to } 1.27)\end{array}$ \\
\hline 220 & 6 & - \\
\hline
\end{tabular}

1200

73

$1.21 \pm 0.03(55)$

(1.17 to 1.30$)$

$105 \quad 18$

$1.21 \pm 0.04(15)$

(1.15 to 1.28 )

$460 \quad 62 \quad 1.28 \pm 0.06(44)$

(1.18 to 1.38 )

$40 \quad 110 \quad 1.33 \pm 0.04(44)$

(1.20 to 1.42 )

cleft

open

230

$1.32 \pm 0.03(27)$

(1.23 to 1.37 ) 
APPENDIX II (continued)

\begin{tabular}{|c|c|c|c|c|c|c|}
\hline $\begin{array}{l}\text { Island } \\
\text { Station }\end{array}$ & Locality & $\begin{array}{l}\text { Latitude } \\
\text { Longitude }\end{array}$ & $\begin{array}{l}\text { Environmental } \\
\text { data }\end{array}$ & $\begin{array}{l}\text { Chlo- } \\
\text { rinity } \\
(\mathrm{mg} / \mathrm{l})\end{array}$ & $\begin{array}{l}N \text { of } \\
\text { speci- } \\
\text { mens }\end{array}$ & $\begin{array}{l}\text { Carapace (mm): } \\
\text { mean length } \\
\pm \text { S.D. }(n) \\
\text { (length range) }\end{array}$ \\
\hline S $79 / 107$ & $\begin{array}{l}\text { Savannah, George Clark's } \\
\text { well }\end{array}$ & $\begin{array}{l}25^{\circ} 04^{\prime} 36^{\prime \prime} \mathrm{N} \\
76^{\circ} 07^{\prime} 37^{\prime \prime} \mathrm{W}\end{array}$ & covered & - & 1 & - \\
\hline S $79 / 108$ & Just $S$. of $S 79 / 107$, well & $\begin{array}{l}25^{\circ} 04^{\prime} 35^{\prime \prime} \mathrm{N} \\
76^{\circ} 07^{\prime} 37^{\prime \prime} \mathrm{W}\end{array}$ & $\begin{array}{l}\text { covered, small } \\
\text { open hole }\end{array}$ & 485 & 6 & - \\
\hline S $79 / 111$ & $\begin{array}{l}\text { The Bluff, Roderick } \\
\text { Pedican's well }\end{array}$ & $\begin{array}{l}25^{\circ} 29^{\prime} 19^{\prime \prime} \mathrm{N} \\
76^{\circ} 44^{\prime} 47^{\prime \prime} \mathrm{W}\end{array}$ & covered & 70 & 16 & - \\
\hline S $79 / 113$ & $\begin{array}{l}\text { The Bluff, close to the } \\
\text { Pier, well }\end{array}$ & $\begin{array}{l}25^{\circ} 29^{\prime} 22^{\prime \prime} \mathrm{N} \\
76^{\circ} 44^{\prime} 49^{\prime \prime} \mathrm{W}\end{array}$ & $\begin{array}{l}\text { covered, oblong } \\
\text { opening }\end{array}$ & 135 & 7 & - \\
\hline S $79 / 114$ & $\begin{array}{l}\text { The Bluff, House the } \\
\text { Hiltons, well }\end{array}$ & $\begin{array}{l}25^{\circ} 29^{\prime} 22^{\prime \prime} \mathrm{N} \\
76^{\circ} 44^{\prime} 48^{\prime \prime} \mathrm{W}\end{array}$ & $\begin{array}{l}\text { covered, oblong } \\
\text { opening }\end{array}$ & 60 & 20 & $\begin{array}{l}1.31 \pm 0.05(19) \\
(1.23 \text { to } 1.39)\end{array}$ \\
\hline S 79/115 & $\begin{array}{l}\text { Sweedy Kelly's well, The } \\
\text { Bluff }\end{array}$ & $\begin{array}{l}25^{\circ} 29^{\prime} 27^{\prime \prime} \mathrm{N} \\
76^{\circ} 44^{\prime} 40^{\prime \prime} \mathrm{W}\end{array}$ & $\begin{array}{l}\text { covered, square } \\
\text { opening }\end{array}$ & 35 & 10 & $\begin{array}{l}1.24 \pm 0.04(10) \\
(1.17 \text { to } 1.28)\end{array}$ \\
\hline S $79 / 117$ & N. of George Town, well & $\begin{array}{l}25^{\circ} 23^{\prime} 39^{\prime \prime} \mathrm{N} \\
76^{\circ} 33^{\prime} 30^{\prime \prime} \mathrm{W}\end{array}$ & $\begin{array}{l}\text { open, square } \\
\text { opening }\end{array}$ & 530 & 36 & $\begin{array}{l}1.23 \pm 0.03(28) \\
(1.20 \text { to } 1.30)\end{array}$ \\
\hline S $79 / 118$ & $\begin{array}{l}\text { Savannah Sound, Saint } \\
\text { Fleur's well }\end{array}$ & $\begin{array}{l}25^{\circ} 04^{\prime} 13^{\prime \prime} \mathrm{N} \\
76^{\circ} 07^{\prime} 42^{\prime \prime} \mathrm{W}\end{array}$ & covered & 1750 & 2 & - \\
\hline S $79 / 120$ & $\begin{array}{l}\text { Savannah Sound (S.E.), } \\
\text { grassland, well }\end{array}$ & $\begin{array}{l}25^{\circ} 04^{\prime} 44^{\prime \prime} \mathrm{N} \\
76^{\circ} 07^{\prime} 40^{\prime \prime} \mathrm{W}\end{array}$ & $\begin{array}{l}\text { square opening, } \\
\text { rubbish }\end{array}$ & 305 & 5 & - \\
\hline
\end{tabular}

